\title{
Acceptability by Girolando heifers and nutritional value of erect prickly pear stored for different periods
}

\author{
Evannielly Thuanny dos Santos Silva(1), Airon Aparecido Silva de Melo(1), \\ Marcelo de Andrade Ferreira(2), Júlio César Vieira de Oliveira ${ }^{(3)}$, Djalma Cordeiro dos Santos ${ }^{(3)}$, \\ Randerson Cavalcante Silva ${ }^{(4)}$ and Jonas Gomes Inácio(2)
}

\begin{abstract}
(1)Universidade Federal Rural de Pernambuco (UFRPE), Unidade Acadêmica de Garanhuns, CEP 55292-270 Garanhuns, PE, Brazil. E-mail: evanniellysilva@hotmail.com, aironuag@hotmail.com (2)UFRPE, Rua Dom Manoel de Medeiros, s/no, Dois Irmãos, CEP 52171-900 Recife, PE, Brazil. E-mail: marcelo.aferreira@ufrpe.br, jonaseafc@yahoo.com.br ${ }^{(3)}$ Instituto Agronômico de Pernambuco, Estação Experimental de Arcoverde, CEP 56500-000 Arcoverde, PE, Brazil. E-mail: juliozootec7@gmail.com, djalma.cordeiro@ipa.br (4)Instituto Federal de Educação, Ciência e Tecnologia de Alagoas, Campus Piranhas, Avenida Sergipe, s/nº, Xingó, CEP 57460-000 Piranhas, AL, Brazil. E-mail: randerson.cavalcante@hotmail.com
\end{abstract}

\begin{abstract}
The objective of this work was to evaluate the nutritional value of erect prickly pear (EPP) (Opuntia stricta), stored for different periods, and its acceptability by Girolando heifers. Five heifers were distributed in a $5 \times 5$ Latin square. The treatments were as follows: EPP without storage time; stored EPP for three post-harvest periods - 7, 14, and 21 days; and cochineal nopal cactus (CNC) (Nopalea cochenillifera) without storage time, as a control treatment. The diets offered to the animals were composed of cacti of the different treatments, as well as sugarcane silage and soybean meal, and were evaluated for their chemical composition, intake, and nutrient digestibility. The ingestive behavior of the heifers was evaluated. The cactus EPP did not differ from the $\mathrm{CNC}$ for organic matter, crude protein, neutral detergent fiber corrected for ash and protein, nonfibrous carbohydrates, total carbohydrates, ether extract, and mineral matter; however, EPP stored for different periods differed from $\mathrm{CNC}$ for dry matter and indigestible neutral detergent fiber. Heifer weights varied $1.35 \mathrm{~kg}$ with the low inclusion of concentrate in the diet. The cactus erect prickly pear maintains constant both its nutritional value and its acceptability to Girolando heifers, after storage for different periods up to 21 days.

Index terms: Nopalea cochinellifera, Opuntia stricta, Brazilian Semiarid Region, cochineal nopal cactus, forage cactus, post-harvest.

\section{Aceitabilidade por novilhas Girolando e valor nutricional da palma orelha-de-elefante-mexicana armazenada por diferentes períodos}

Resumo - O objetivo deste trabalho foi avaliar o valor nutricional da palma orelha-de-elefante-mexicana (OEM) (Opuntia stricta), armazenada por diferentes períodos, e sua aceitabilidade por novilhas Girolando. Foram utilizadas cinco novilhas distribuídas em quadrado latino 5x5. Os tratamentos foram os seguintes: palma OEM, sem armazenamento; OEM armazenada por três períodos pós-colheita - 7, 14 e 21 dias; e palma-miúda (PM) (Nopalea cochenillifera) sem armazenamento, como tratamento controle. As dietas oferecidas aos animais foram compostas de palmas dos diferentes tratamentos, assim como silagem de cana-de-açúcar e farelo de soja, e foram avaliadas quanto à composição químico-bromatológica, consumo e digestibilidade dos nutrientes. O comportamento ingestivo das novilhas foi avaliado. A palma OEM não diferiu da PM quanto à matéria orgânica, proteína bruta, fibra em detergente neutro corrigida quanto às cinzas e proteína, carboidratos não fibrosos, carboidratos totais, extrato etéreo e matéria mineral; no entanto, a palma OEM diferiu da PM quanto à matéria seca e à fibra em detergente neutro indigestível, quando armazenada por diferentes períodos. O peso das novilhas variou em $1,35 \mathrm{~kg}$, com a baixa inclusão de concentrado na dieta. A palma orelha-de-elefante-mexicana mantém constante seu valor nutricional e sua aceitabilidade pelas novilhas Girolando, após armazenamento por diferentes períodos até 21 dias.

Termos para indexação: Nopalea cochinellifera, Opuntia stricta, Semiárido brasileiro, palma-miúda, palmaforrageira, pós-colheita.

\section{Introduction}

The milk production system in the Brazilian Semiarid Region, notably in the Northeastern, is predominantly reliant on family farming. In a survey conducted in the main milk production center of Pernambuco state, Oliveira (2013) reported that $83.33 \%$ of the land were owned by families. The areas had up to 37.2 ha, and 
showed a low volume of milk produced per day, and an incipient level of technology. In the evaluated systems, $90 \%$ of the rural properties used the Indian-fig cactus (Opuntia ficus-indica Mill.), cultivar Gigante, as a forage resource. However, the insect prickly pear cochineal (Dactylopius opuntiae) expanded slowly through the cactus fields, decimating or compromising the productivity of thousands of hectares of spineless cactus.

Therefore, the Instituto Agronônimo de Pernambuco (IPA) and the Universidade Federal Rural de Pernambuco (UFRPE) have been selecting clones of forage cactus resistant to prickly pear cochineal. The genotypes $O$. stricta Haw., N. cochenillifera SalmDyck, O. undulata Griffiths, and $N$. cochenillifera 'IPA-Sertânia' were identified as resistant to the prickly pear cochineal (Santos et al., 2006; Vasconcelos et al., 2009). Among these plant species, O. stricta is the less-demanding cactus for nutrients and more tolerant to water stress conditions, besides showing a higher-dry matter production per unit area than the other genotypes. Depending on the structure of the cultivation, O. stricta is harvested manually and transported by animal traction to its place of use. In general, this operation is performed daily, increasing the production costs, which represents approximately $40 \%$ of the total cropping costs (Santos et al., 2006). The harvesting of large volumes and the storage for long periods could contribute to decrease such costs (Santos et al., 1992, 1998). Because there are few reports on the storage of cactus - mainly the erect prickly pear, which has recently been imported from Mexico -, more studies are needed on this cactus post-harvest management for long-term use, without altering its nutritional value. This could reduce the production costs, mainly those related to labor, and increase the efficiency of the production system.

The objective of this work was to evaluate the nutritional value of the erect prickly pear stored for different times, and its acceptability to Girolando heifers.

\section{Materials and Methods}

The experiment was conducted at the experimental station of the Instituto Agronômico de Pernambuco, in the municipality of Arcoverde, PE, Brazil $\left(08^{\circ} 25^{\prime} 08^{\prime \prime} \mathrm{S}\right.$, $37^{\circ} 03^{\prime} 14^{\prime \prime} \mathrm{W}$, at $663 \mathrm{~m}$ altitude).
Five Girolando heifers (5/8 Holstein-Gir), with a $284 \mathrm{~kg}$ mean initial body weight, were used. The heifers were distributed in a $5 \times 5$ Latin square. The adaptation of the animals to the facilities and the management took place during 15 days. During the first ten days, the animals adapted to the diets. The other five days were used for data collection and sampling. The experimental period was 75 days divided into five periods of 15 days. Forage cactus $\mathrm{pH}$ was determined during the five days of data collection, using a portable pH meter (Nova Instruments, Piracicaba, SP, Brazil).

The heifers were confined in individual stalls equipped with drinking fountains and feeders. We formulated the diets to provide a weight gain of $1.2 \mathrm{~kg}$ per day (NRC, 2001). The diets consisted of 50\% erect prickly pears, or $50 \%$ cochineal nopal cactus, $30 \%$ sugarcane silage, and $20 \%$ concentrate ( $94 \%$ soybean meal, $2 \%$ common salt, $4 \%$ mineral blend) (Table 1 ). The feed was provided ad libitum in the form of total mixture, divided into two meals per day - at 08:00 and $16: 00 \mathrm{~h}$, allowing up to $10 \%$ leftovers of the total dry matter supplied. Food leftovers were daily weighed prior to the morning meal, to estimate the food intake and adjust the supply.

The treatments were: erect prickly pear without storage time; erect prickly pear stored for three postharvest periods (7, 14, and 21 days); and cochineal nopal cactus, without storage, as a control treatment.

We cut the racket-shaped leaves of erect prickly pear with over four years without previous cuts, on the secondary cladode, and stored them in a covered masonry shed, provided with natural ventilation, on top of wood platforms stacked up to $80 \mathrm{~kg}$.

Heifers were weighed on the first day of adaptation, and at the end of each experimental period, in the morning, before feeding.

During the collection period (from the $11^{\text {th }}$ to the $15^{\text {th }}$ day), in two shifts, we collected the following samples of ingredients: cactus from the different treatments; sugarcane silage; soybean meal; and leftovers. The feces of the heifers were directly collected from a rectal ampulla once a day, at 6,8 , 10,12 , and $14 \mathrm{~h}$, from the $11^{\text {th }}$ to the $15^{\text {th }}$ day of each experimental period. All samples were stored at $-18^{\circ} \mathrm{C}$ for further drying and chemical analyses.

At the end of the experiment, food samples, leftovers, and feces were thawed, pre-dried in a forced-air ventilation oven $\left(\right.$ at $60^{\circ} \mathrm{C}$, until the obtention of constant dry matter), and ground with a Willey knife-type mill 
(Marconi Equipamentos para Laboratórios Ltda., Piracicaba, SP, Brazil), using sieves of $1 \mathrm{~mm}$ mesh for chemical analyses, and of $2 \mathrm{~mm}$ mesh for in situ ruminal incubation, for the further determination of the internal indicator of indigestible neutral detergent fiber (iNDF). After drying, we obtained the composite samples of each animal, for each experimental period (feces, ingredients, and leftovers).

Dry matter and nutrient intakes were determined by the difference between the amounts of food supplied and the leftovers. Fecal dry matter production (FDMP) was estimated using the iNDF indicator. The apparent digestibility coefficient (ADC) of the nutrients was calculated by the equation $\mathrm{ADC}=$ (nutrient intake excreted nutrient) / nutrient intake.

The analyses of dry matter (DM), organic matter $(\mathrm{OM})$, mineral matter (MM), ether extract (EE), and crude protein $(\mathrm{CP})$ were performed according to methods described by the AOAC (Helrich, 1990). The analyses of neutral detergent fiber (NDF), acid detergent fiber (ADF), and NDF corrected for ash and protein (NDFap) were performed according to Van Soest et al. (1991), with the changes suggested by Senger et al. (2008), using autoclave at $110^{\circ} \mathrm{C}$ for $40 \mathrm{~min}$.

The NDFap ( $\%$ of DM) was expressed by the equation NDFap = NDF - NDIP - NDIA, in which: NDIP is the neutral detergent insoluble protein content, and $\mathrm{NDIP}=($ neutral detergent insoluble nitrogen $\times 6.25)$; NDF $(\%$ of DM $) ;$ NDIP $=(\%$ of NDF $)$; NDIA is the neutral detergent insoluble ash, and NDIA $=(\%$ of NDF).
To determine the lignin content, the solubilization of cellulose was performed in sulfuric acid at $72 \%$, according to the methodology proposed by Van Soest et al. (1991). The analyses of NDIP and acid detergent insoluble protein (ADIP) were performed according to Licitra et al. (1996). The estimates of indigestible neutral detergent fiber (iNDF) of food, leftover, and feces samples were performed by in situ incubation for 288 hours (Valente et al., 2011), for the subsequent estimation of fecal dry matter production using the internal indicator iNDF.

For the estimation of total carbohydrates (TC) and total digestible nutrient intake (TDNI), the following equations were proposed by Sniffen et al. (1992): $\mathrm{TC}=100-(\% \mathrm{CP}+\% \mathrm{EE}+\% \mathrm{MM})$, and $\mathrm{TDNI}=\mathrm{CPd}+\mathrm{TCd}+2.25 \mathrm{EEd}$, in which: $\mathrm{CPd}$ is the digestible crude protein; TCd is the digestible total carbohydrates; EEd is the digestible ether extract; and TDN $(\%)=[($ TDN intake / DM intake $) \times 100]$, in which TDN is the total digestible nutrient. Nonfibrous carbohydrates (NFC) were calculated by the difference between TC and NDF.

The method chosen for data collection was the observation of animal behavior according to the instantaneous scanning method (Martin \& Bateson, 2007), during a period of 24 hours, at 5 min intervals, in the $11^{\text {th }}$ and in the $12^{\text {th }}$ days of each experimental period. Observations began at 08:00 h on one day, and finished at $08: 00 \mathrm{~h}$ on the following day. The behavioral variables were rest, rumination, feeding, and chewing (feeding + rumination).

To determine the time that the animal destined to feeding, we considered the feeding time in hours,

Table 1. Chemical composition of ingredients of the experimental diets.

\begin{tabular}{|c|c|c|c|c|}
\hline \multirow[t]{2}{*}{ Composition } & \multicolumn{4}{|c|}{ Ingredient } \\
\hline & Sugarcane silage & Cochineal nopal cactus & Soybean meal & Erect prickly pear cactus \\
\hline $\mathrm{DM}\left(\mathrm{g} \mathrm{kg}^{-1}\right.$ as fed $)$ & 391.7 & 140.2 & 882.5 & 127.3 \\
\hline $\mathrm{OM}$ ( $\mathrm{g} \mathrm{kg}^{-1}$ dry matter $)$ & 867.5 & 913.2 & 936.6 & 914.7 \\
\hline Ashes ( $\mathrm{g} \mathrm{kg}^{-1}$ dry matter) & 132.5 & 86.8 & 63.4 & 85.3 \\
\hline $\mathrm{CP}\left(\mathrm{g} \mathrm{kg}^{-1}\right.$ dry matter $)$ & 13.7 & 32.5 & 449.4 & 33.2 \\
\hline NDFap ( $\mathrm{g} \mathrm{kg}^{-1}$ dry matter) & 559.9 & 202.2 & 137.5 & 227.4 \\
\hline $\mathrm{ADF}\left(\mathrm{g} \mathrm{kg}^{-1}\right.$ dry matter $)$ & 474.0 & 200.1 & 87.4 & 172.9 \\
\hline Lignin ( $\mathrm{g} \mathrm{kg}^{-1}$ dry matter) & 195.6 & 93.3 & 16.2 & 108.0 \\
\hline NFC ( $\mathrm{g} \mathrm{kg}^{-1}$ dry matter $)$ & 285.3 & 667.4 & 286.4 & 642.2 \\
\hline TC ( $\mathrm{g} \mathrm{kg}^{-1}$ dry matter) & 845.2 & 869.5 & 423.9 & 869.6 \\
\hline iNDF ( $\mathrm{g} \mathrm{kg}^{-1}$ dry matter) & 391.5 & 146.3 & 27.6 & 89.6 \\
\hline $\mathrm{EE}\left(\mathrm{g} \mathrm{kg}^{-1}\right.$ dry matter $)$ & 9.6 & 11.3 & 12.4 & 12.2 \\
\hline
\end{tabular}

${ }^{(1)} \mathrm{DM}$, dry matter; OM, organic matter; CP, crude protein; NDFap, neutral detergent fiber corrected for ash and protein; ADF, acid detergent fiber; NFC, nonfibrous carbohydrates; TC, total carbohydrates; and iNDF, indigestible neutral detergent fiber; EE, ether extract. 
including intake, chewing, and the swallowing of the feed bolus. The variable rumination was calculated taking into account the time spent with regurgitation, re-chewing and re-swallowing of the food bolus. For the time spent with rest, we considered the time that the animals took to lie down, stand up and sleep, that is, the time without feeding and rumination.

Feed (FE) and rumination (RE) efficiencies were calculated according to the following equations: $\mathrm{FE}=\mathrm{DM}$ intake (kg) / feeding time (h); RE = DM intake $(\mathrm{kg})$ / rumination time (h); and $\mathrm{RE} / \mathrm{NDF}=$ intake of NDFap ( $\mathrm{kg}) /$ rumination time (h).

The statistical analysis used the following model: $\mathrm{Y}_{\mathrm{ijkl}}=\mu+\mathrm{Q}_{\mathrm{i}}+\mathrm{T}_{\mathrm{j}}+(\mathrm{P} / \mathrm{Q})_{\mathrm{ik}}+(\mathrm{V} / \mathrm{Q})_{\mathrm{il}}+\mathrm{e}_{\mathrm{ijk} \mathrm{k}}$, in which: $\mathrm{Y}_{\mathrm{ijkl}}$ is the observation of the animal 1, during the $\mathrm{k}$ period, subjected to the treatment $\mathrm{j} ; \mu$ is the general constant; $Q_{i}$ is the effect of the Latin square $i$, in which $\mathrm{i}=1 ; \mathrm{T}_{\mathrm{j}}$ is the effect of the treatment $\mathrm{j}$, in which $\mathrm{j}=1$, 2, 3, 4 and 5; $(\mathrm{P} / \mathrm{Q})_{\mathrm{ik}}$ is the effect of period $\mathrm{k}$ within the Latin square $\mathrm{i}$, in which $\mathrm{k}=1,2,3,4$, and $5 ;(\mathrm{V} / \mathrm{Q})$ il is the effect of animal 1 within the Latin square $i$, in which $1=1,2,3,4$, and 5; and $\mathrm{e}_{\mathrm{ijkl}}$ is the random error associated with each observation, assuming the NID $(0 ; \sigma 2)$.

Data were subjected to the analysis of variance and regression, using the GLM and REG procedures of SAS (SAS Institute Inc., Cary, NC, EUA) for data analysis, at $5 \%$ probability. The variables were subjected to Dunnet's test, at 5\% probability, considering the cochineal nopal cactus treatment as a control.

\section{Results and Discussion}

The chemical composition of cochineal nopal cactus, without storage time, and of erect prickly pear, after different storage times, did not differ for OM, CP, NDFap, NFC, total carbohydrates (TC), EE, and MM (Table 2), except for DM and iNDF. Cochineal nopal cactus did not differ from erect prickly pear without storage time, for DM, however, they differed in the treatments with 7, 14, and 21 days of storage.

The average chemical composition of erect prickly pear and cochineal nopal cactus (Table 2) is in agreement with previous studies conducted on these plant materials (Rocha Filho, 2012; Conceição et al., 2016).

Santos et al. (1992) observed no apparent losses of $\mathrm{DM}$ and other chemical components for the cultivars Sweet, Gigante, and Redonda, under storage conditions with natural ventilation. The DM of cochineal nopal cactus $\left(233.9 \mathrm{~g} \mathrm{~kg}^{-1}\right)$, obtained by those authors, was higher than the DM of other cultivars, but this variation was attributed to the time of year, when the cactus was harvested and stored, that is, during the dry period in the region.

In the comparison of the storage times of erect prickly pear, there was an increasing linear effect $(\mathrm{p}<0.05)$ for $\mathrm{MM}$ and $\mathrm{CP}$, and a decreasing linear effect $(\mathrm{p}<0.05)$ for OM and TC (Table 2).

Levels of total carbohydrates decreased linearly during storage. Crude protein and ash levels increased. Such changes found in the chemical composition

Table 2. Chemical composition of cochineal nopal cactus (CNC, Nopalea cochenillifera) and erect prickly pear (Opuntia stricta) stored for 7,14 , and 21 days.

\begin{tabular}{|c|c|c|c|c|c|c|c|c|c|}
\hline \multirow[t]{2}{*}{ Nutrient } & \multirow[t]{2}{*}{$\mathrm{CNC}^{(1)}$} & \multicolumn{4}{|c|}{ Erect prickly pear (days of storage) } & \multirow[t]{2}{*}{ SEM } & \multicolumn{3}{|c|}{ p-value } \\
\hline & & 0 & 7 & 14 & 21 & & $\mathrm{D}$ & L & Q \\
\hline $\mathrm{DM}\left(\mathrm{g} \mathrm{kg}^{-1}\right.$ as fed $)$ & $140.2 \mathrm{a}$ & $127.3 \mathrm{a}$ & $118.9 \mathrm{~b}$ & $118.9 \mathrm{~b}$ & $116.9 \mathrm{~b}$ & 3.93 & 0.039 & 0.209 & $>0.05$ \\
\hline OM ( $\mathrm{g} \mathrm{kg}^{-1}$ dry matter $)$ & 913.2 & 914.7 & 904.3 & 896.2 & 885.1 & 5.08 & 0.124 & 0.013 & $>0.05$ \\
\hline MM ( $\mathrm{g} \mathrm{kg}^{-1}$ dry matter) & 86.8 & 85.3 & 95.7 & 103.8 & 114.9 & 5.08 & 0.124 & 0.013 & $>0.05$ \\
\hline $\mathrm{CP}\left(\mathrm{g} \mathrm{kg}^{-1}\right.$ dry matter $)$ & 32.5 & 33.2 & 32.8 & 44.2 & 44.1 & 2.73 & 0.088 & 0.025 & $>0.05$ \\
\hline NDFap ( $\mathrm{g} \mathrm{kg}^{-1}$ dry matter) & 202.2 & 227.4 & 177.3 & 212.2 & 203.1 & 9.04 & 0.413 & $>0.05$ & $>0.05$ \\
\hline NFC ( $\mathrm{g} \mathrm{kg}^{-1}$ dry matter) & 667.4 & 642.2 & 680.6 & 626.8 & 624.3 & 11.82 & $>0.05$ & 0.316 & $>0.05$ \\
\hline $\mathrm{TC}$ ( $\mathrm{g} \mathrm{kg}^{-1}$ dry matter) & 869.5 & 869.6 & 857.9 & 839.1 & 827.5 & 7.85 & 0.083 & 0.010 & $>0.05$ \\
\hline iNDF ( $\mathrm{g} \mathrm{kg}^{-1}$ dry matter) & $146.3 \mathrm{a}$ & $89.6 b$ & $89.1 b$ & $91.2 b$ & $97.1 b$ & 5.38 & $<0.05$ & $>0.05$ & $>0.05$ \\
\hline $\mathrm{EE}\left(\mathrm{g} \mathrm{kg}^{-1}\right.$ dry matter$)$ & 11.3 & 12.2 & 13.8 & 13.9 & 13.7 & 0.51 & 0.375 & $>0.05$ & $>0.05$ \\
\hline $\mathrm{ADF}$ & 200.1 & 172.9 & 155.2 & 189.4 & 188.4 & 3.50 & $>0.05$ & $>0.05$ & 0.07 \\
\hline Lignin & 93.3 & 108.0 & 118.6 & 95.4 & 96.0 & 2.16 & $>0.05$ & $>0.05$ & 0.19 \\
\hline$\underline{\mathrm{pH}}$ & $5.01 \mathrm{a}$ & $4.59 \mathrm{~b}$ & $4.79 \mathrm{~b}$ & $4.95 \mathrm{a}$ & $5.00 \mathrm{a}$ & 0.06 & $<0.05$ & $<0.05$ & $>0.05$ \\
\hline
\end{tabular}

${ }^{(1)}$ Without storage. DM, dry matter; OM, organic matter; MM, mineral matter; CP, crude protein; NDFap, neutral detergent fiber corrected for ash and protein; NFC, nonfibrous carbohydrates; TC, total carbohydrates; iNDF, indigestible neutral detergent fiber; EE, ether extract; ADF, acid detergent fiber; $\mathrm{pH}$, hydrogen potential; SEM, standard error of the mean; D, Dunnet's test, at 5\% probability; L, linear effect; and Q, quadratic effect. 
of erect prickly pear may be a consequence of the continuation of vital plant processes, such as respiration and microbial aerobic activity over time, which was evidenced by the $\mathrm{pH}$ increase 14 days after harvesting the cactus (Table 2).

The $\mathrm{pH}$ values for cochineal nopal cactus and erect prickly pear differed according to storage times, except for $\mathrm{pH}$ at 14 and 21 days of storage (Table 2). This variation of $\mathrm{pH}$ could lead to some changes of intake by the animals, but the inclusion of the cacti was $50 \%$ in the diet, and there were no changes in the intake.

Experimental diets met the nutritional requirements for growing heifers (NRC, 2001). The DM consumption, DM as percentage of body weight (DMPBW), OM, digestible OM (DOM), NDF, and total digestible nutrients (TDN) did not differ from the control treatment (Table 3). This indicates that all treatments can be used without interferences in the animal performance.

However, there was an increasing linear effect for $\mathrm{CP}$ intake, according to the different times of storage of the erect prickly pear. Possibly, these cactus CP content increased due to $\mathrm{OM}$ losses according to storage time.

The results of the consumption of $\mathrm{DM} \% \mathrm{CP}$ were similar to those found by Almeida et al. (2015) for the cactus 'Gigante' in supplements for growing dairy cows, and by Monteiro et al. (2014) when replacing wheat bran, 'Gigante', and urea in the diets of Girolando heifers.

The apparent digestibility coefficients of DM, $\mathrm{OM}, \mathrm{CP}$, and NDFap did not differ from the control treatment. Storage times did not influence nutrient digestibility.

As to the variation of animal weight, there were no differences between the erect prickly pear and the control treatment, as well as no effects of storage times. Heifers had a mean daily weight gain of $1.350 \mathrm{~kg}$ per day. The daily requirements for dairy females, with $307 \mathrm{~kg}$ mean weight, and $1.350 \mathrm{~kg}$ per day weight gain, were 5.5 and $0.991 \mathrm{~kg}$ of TDN and CP, respectively. The mean values (Table 3 ) were similar to those required by the NRC (2001), that is, 5.3 and 0.992 for TDN and CP, respectively. It is worth noting the small proportion of concentrate used $(20 \%)$ to reach such weight variation. This was probably due to a high proportion of cactus in the diets $(50 \%)$.

The parameters evaluated for the intake behavior of heifers (Table 4) fed erect prickly pear did not differ from the results obtained for feeding them with cochineal nopal cactus. There were no effects of storage times on the erect prickly pear, which indicates that, despite the high palatability of cochineal nopal cactus beacause of its high-carbohydrate content (Santos et al., 2001; Rocha Filho, 2012), the diets were not selected differently by the animals.

Table 3. Intake and digestibility of nutrients in Girolando heifers fed cochineal nopal cactus (CNC, Nopalea cochenillifera) and erect prickly pear (Opuntia stricta) stored for 7, 14, and 21 days.

\begin{tabular}{|c|c|c|c|c|c|c|c|c|c|}
\hline \multirow{2}{*}{$\begin{array}{l}\text { Intake } \\
\text { (kg per day) }\end{array}$} & \multirow[t]{2}{*}{$\mathrm{CNC}^{(1)}$} & \multicolumn{4}{|c|}{ Erect prickly pear (days of storage) } & \multirow[t]{2}{*}{ SEM } & \multicolumn{3}{|c|}{ p-value } \\
\hline & & 0 & 7 & 14 & 21 & & $\mathrm{D}$ & $\mathrm{L}$ & Q \\
\hline $\mathrm{DM}$ & 8.49 & 8.38 & 8.02 & 9.25 & 8.84 & 0.34 & 0.170 & 0.094 & $>0.05$ \\
\hline DM (\% BW) & 2.47 & 2.49 & 2.38 & 2.71 & 2.59 & 0.10 & 0.210 & $>0.05$ & 0.173 \\
\hline $\mathrm{OM}$ & 7.68 & 7.60 & 7.23 & 8.28 & 7.89 & 0.29 & 0.197 & 0.157 & $>0.05$ \\
\hline DOM & 5.39 & 5.53 & 5.24 & 6.14 & 5.65 & 0.20 & 0.061 & 0.188 & $>0.05$ \\
\hline NDFap & 2.14 & 2.32 & 2.01 & 2.43 & 2.31 & 0.16 & 0.422 & $>0.05$ & $>0.05$ \\
\hline $\mathrm{CP}$ & 0.97 & 0.93 & 0.90 & 1.12 & 1.04 & 0.05 & 0.060 & 0.032 & $>0.05$ \\
\hline TDN & 5.04 & 5.14 & 5.03 & 5.93 & 5.38 & 0.23 & 0.086 & 0.146 & $>0.05$ \\
\hline \multicolumn{10}{|l|}{ Digestibility (g per day) } \\
\hline $\mathrm{DM}$ & 633.40 & 673.32 & 668.73 & 691.36 & 654.85 & 14.33 & 0.120 & $>0.05$ & 0.317 \\
\hline $\mathrm{OM}$ & 702.86 & 727.37 & 725.82 & 743.05 & 716.56 & 12.99 & 0.326 & $>0.05$ & $>0.05$ \\
\hline $\mathrm{CP}$ & 655.13 & 656.77 & 672.02 & 717.47 & 678.39 & 23.52 & 0.380 & 0.280 & 0.237 \\
\hline NDFap & 522.58 & 622.05 & 536.53 & 590.86 & 592.84 & 34.45 & 0.271 & $>0.05$ & 0.150 \\
\hline Weight variation (kg per day) & 1.36 & 1.43 & 1.39 & 1.46 & 1.13 & 0.14 & 0.120 & $>0.05$ & $>0.05$ \\
\hline
\end{tabular}

${ }^{(1)}$ Without storage. DM, dry matter; BW, body weight; OM, organic matter; DOM, digestible organic matter; NDFap, neutral detergent fiber corrected for ash and protein; CP, crude protein; and TDN, total digestible nutrient. SEM, standard error of the mean; D, Dunnet's test; L, linear effect; Q, quadratic effect, at $5 \%$ probability. 
Table 4. Ingestive behavior of Girolando heifers in consequence of cochineal nopal cactus (CNC, Nopalea cochenillifera) and the storage period of erect prickly pear (Opuntia stricta).

\begin{tabular}{|c|c|c|c|c|c|c|c|c|c|}
\hline \multirow[t]{2}{*}{ Variable } & \multirow[t]{2}{*}{$\mathrm{CNC}^{(1)}$} & \multicolumn{4}{|c|}{ Erect prickly pear (days of storage) } & \multirow[t]{2}{*}{ SEM } & \multicolumn{3}{|c|}{$\mathrm{p}$} \\
\hline & & 0 & 7 & 14 & 21 & & D & $\mathrm{L}$ & Q \\
\hline Feeding (h) & 5.40 & 4.68 & 4.75 & 5.58 & 5.07 & 0.22 & 0.176 & 0.142 & 0.315 \\
\hline Rumination (h) & 6.97 & 6.98 & 6.77 & 6.73 & 7.58 & 0.19 & $>0.05$ & 0.333 & 0.202 \\
\hline Idle (h) & 11.63 & 12.33 & 12.48 & 11.68 & 11.35 & 0.26 & 0.265 & 0.140 & $>0.05$ \\
\hline Total chewing & 12.37 & 11.67 & 11.52 & 12.32 & 12.65 & 0.26 & 0.265 & 0.140 & $>0.05$ \\
\hline Feed efficiency ${ }^{(2)}$ & 1.58 & 1.88 & 1.77 & 1.75 & 1.80 & 0.08 & 0.249 & $>0.05$ & $>0.05$ \\
\hline Rumination efficiency ${ }^{(3)}$ & 1.22 & 1.20 & 1.23 & 1.39 & 1.19 & 0.04 & $>0.05$ & $>0.05$ & 0.298 \\
\hline Rumination per $\mathrm{kg}^{-1}$ of NDFap & 0.31 & 0.33 & 0.31 & 0.36 & 0.31 & 0.01 & $>0.05$ & $>0.05$ & $>0.05$ \\
\hline
\end{tabular}

${ }^{(1)}$ Without storage. (2)Dry matter intake (DMI h ${ }^{-1}$ ) of feeding. ${ }^{(3)} \mathrm{DMI} \mathrm{h}^{-1}$ of rumination. SEM, standard error of the mean; D, Dunnet's test; L, linear effect; and Q, quadratic effect, at 5\% probability. NDFap, neutral detergent fiber corrected for ash and protein.

The animals showed a good stimulation for total chewing, mostly taking approximately 12 hours for this activity. This was possible due to the NDF content of the experimental diets, according to the NRC (2001). NDF provided an adequate $\mathrm{pH}$ for normal ruminal conditions, salivary secretion, and an appropriate environment for ruminal fermentation.

\section{Conclusions}

1. Erect prickly pear (Opuntia stricta) maintains its nutritional value stable, when subjected to different storage times up to 21 days.

2. The intake behavior of Girolando heifers does not differ between treatments with erect prickly pear (nonstored, or stored for 7, 14, and 21 days), and the cochineal nopal cactus (control).

\section{Acknowledgments}

To Coordenação de Aperfeiçoamento de Pessoal de Nível Superior (Capes), for scholarships granted.

\section{References}

ALMEIDA, G.A.P. de; CAMPOS, J.M. de S.; FERREIRA, M. de A.; CORREIA, A.L.V.; ANDRADE, A.P. de. Palma (Opuntia fícus indica Mill) cv. Gigante em suplementos para fêmeas leiteiras em crescimento a pasto. Revista Caatinga, v.28, p.161$171,2015$.

CONCEIÇÃO, M.G. da; FERREIRA, M. de A.; CAMPOS, J.M. de S.; SILVA, J. de L.; DETMANN, E.; SIQUEIRA, M.C.B. de; BARROS, L.J.A. de; COSTA, C.T.F. Replacement of wheat bran with spineless cactus in sugarcane-based diets for steers. Revista Brasileira de Zootecnia, v.45, p.158-164, 2016. DOI: 10.1590/ S1806-92902016000400003.
HELRICH, K. (Ed.). Official methods of analysis of the AOAC. $15^{\text {th }}$ ed. Arglington: Association of Official Analytical Chemists, 1990. 745p.

LICITRA, G.; HERNANDEZ, T.M.; VAN SOEST, P.J. Standardization of procedures for nitrogen fractionation of ruminant feeds. Animal Feed Science and Technology, v.57, p.347-358, 1996. DOI: 10.1016/0377-8401(95)00837-3.

MARTIN, P.; BATESON, P. Measuring behavior: an introductory guide. $3^{\text {rd }}$ ed. Cambrigde: Cambridge University Press, 2007. 186p. DOI: 10.1017/CBO9780511810893.

MONTEIRO, C.C. de F.; MELO, A.A.S. de; FERREIRA, M.A.; CAMPOS, J.M. de S.; SOUZA, J.S.R.; SILVA, E.T. dos S.; ANDRADE, R. de P.X. de; SILVA, E.C. da. Replacement of wheat bran with spineless cactus (Opuntia ficus indica Mill cv Gigante) and urea in the diets of Holstein x Gyr heifers. Tropical Animal Health Production, v.46, p.1149-1154, 2014. DOI: 10.1007/s11250-014-0619-0.

NRC. National Research Council. Nutrient requirements of dairy cattle. $7^{\text {th }}$ rev. ed. Washington: National Academic Press, 2001. 381p. DOI: 10.17226/9825.

OLIVEIRA, M.C. Avaliação técnica, econômica e acompanhamento da qualidade do leite de sistemas de produção de bovinos leiteiros no Agreste pernambucano. 2013. 163p. Dissertação (Mestrado) - Universidade Federal Rural de Pernambuco, Garanhuns.

ROCHA FILHO, R.R. Palma gigante e genótipos resistentes à cochonilha do carmim em dietas para ruminantes. 2012. 74p. Tese (Doutorado) - Universidade Federal Rural de Pernambuco, Recife.

SANTOS, D.C. dos; FARIAS, I.; LIRA, M. de A.; SANTOS, M.V.F. dos; ARRUDA, G.P. de; COELHO, R.S.B.; DIAS, F.M.; MELO, J.N. de. Manejo e utilização da palma forrageira (Opuntia e Nopalea) em Pernambuco. Recife: Empresa Pernambucana de Pesquisa Agropecuária, 2006. 48p. (IPA Documentos, 30).

SANTOS, D.C. dos; SANTOS, M.V.F. dos; FARIAS, I.; DIAS, F.M.; LIRA, M. de A. Desempenho produtivo de vacas $5 / 8$ Holando/Zebu alimentadas com diferentes cultivares de palma forrageira (Opuntia e Nopalea). Revista Brasileira de Zootecnia, v.30, p.12-17, 2001. DOI: 10.1590/S1516-35982001000100003. 
SANTOS, M.V.F. dos; FARIAS, I.; LIRA, M. de A.; NASCIMENTO, M.M.A. do; SANTOS, D.C. dos; TAVARES FILHO, J.J. Colheita da palma forrageira (Opuntia ficus indica Mill) cv. Gigante sobre o desempenho de vacas em lactação. Revista Brasileira de Zootecnia, v.27, p.33-39, 1998.

SANTOS, M.V.F. dos; LIRA, M. de A.; FARIAS, I.; BURITY, H.A.; FILHO, J.J.T. Efeito do período de armazenamento póscolheita sobre o teor de matéria seca e composição química das palmas forrageiras. Pesquisa Agropecuária Brasileira, v.27, p.777-783, 1992.

SENGER, C.C.D.; KOZLOSKI, G.V.; BONNECARRÈRE SANCHEZ, L.M.; MESQUITA, F.R.; ALVES, T.P.; CASTAGNINO, D.S. Evaluation of autoclave procedures for fibre analysis in forage and concentrate feedstuffs. Animal Feed Science and Technology, v.146, p.169-174, 2008. DOI: 10.1016/j. anifeedsci.2007.12.008.

SNIFFEN, C.J.; O'CONNOR, J.D.; VAN SOEST, P.J.; FOX, D.G.; RUSSELL, J.B. A net carbohydrate and protein system for evaluating cattle diets: II. Carbohydrate and protein availability.
Journal of Animal Science, v.70, p.3562-3577, 1992. DOI: 10.2527/1992.70113562x.

VALENTE, T.N.P.; DETMANN, E.; QUEIROZ, A.C. de; VALADARES FILHO, S.C.; GOMES, D.I.; FIGUEIRAS, J.F. Evaluation of ruminal degradation profiles of forages using bags made from different textiles. Revista Brasileira de Zootecnia, v.40, p.2565-2573, 2011. DOI: 10.1590/S1516-35982011001100039.

VAN SOEST, P.J.; ROBERTSON, J.B.; LEWIS, B.A. Methods for dietary fiber, neutral detergent fiber, and nonstarch polysaccharides in relation to animal nutrition. Journal of Dairy Science, v.74, p.3583-3597, 1991. DOI: 10.3168/jds.S0022-0302(91)78551-2.

VASCONCELOS, A.G.V. de; LIRA, M. de A.; CAVALCANTI, V.L.B.; SANTOS, M.V.F. dos; WILLADINO, L. Seleção de clones de palma forrageira resistentes à cochonilha-do-carmim (Dactylopius sp). Revista Brasileira de Zootecnia, v.38, p.827831, 2009. DOI: 10.1590/S1516-35982009000500007.

Received on September 29, 2016 and accepted on January 30, 2017 